[Note]

\title{
Supercritical Water Liquefaction of Coal and Waste Tires: Effects of Partial Oxidation and the Water-gas Shift Reaction
}

\author{
Prapan KuCHONTHARA ${ }^{\dagger 1 *}$ and Yukihiko Matsumura ${ }^{\dagger 2)}$ \\ t1) Dept. of Chemical System Engineering, The University of Tokyo, 7-3-1 Hongo, Bunkyo-ku, Tokyo 113-8656, JAPAN \\ †2) Dept. of Mechanical System Engineering, Hiroshima University, 1-4-1 Kagamiyama, Higashi-hiroshima, Hiroshima 739-8527, JAPAN
}

(Received May 8, 2001)

\begin{abstract}
Supercritical water liquefaction of scrap tire rubber and Ishikari coal, separately and in mixtures was investigated to study the possible synergetic effects of coliquefaction between the feedstocks. The effects of partial oxidation on the liquefaction characteristics caused by the water-gas shift reaction in supercritical water were also investigated. Liquefaction was carried out in a tube-bomb reactor at $673 \mathrm{~K}$ and $25 \mathrm{MPa}$, in the presence and absence of Ni catalyst. The Ni catalyst increased the content of $\mathrm{H}_{2}$ and decreased the content of $\mathrm{CO}$ in the gas product for both separate and mixture liquefaction, indicating that the water-gas shift reaction was increased by the $\mathrm{Ni}$ catalyst. Carbon conversion for coal-tire coliquefaction was greater than the average of the separate conversions, especially when using the Ni catalyst.
\end{abstract}

\section{Introduction}

Waste tires have become a severe environmental and economic problem worldwide. Annually, approximately 10 million tires are dumped in Australia, Japan, and Thailand, 35 million tires in the UK and 250 million tires in the $\mathrm{USA}^{1)-3)}$. Disposal of this large amount of waste tires is usually in landfill sites. Compared to the total of waste materials, discarded tires account for only a small percentage, but their nonbiodegradable and burnable properties cause health problems and fire hazards. Therefore, disposal of waste tires as landfill or dumping in the open air are not desirable. Recovery of the raw materials is impossible because of the vulcanization process. An alternative method of disposal is burning to utilize the high heat of combustion (29-37 MJ/kg), which is higher than most coals. Combustion has great potential for energy recovery, but emission of $\mathrm{NO}_{x}, \mathrm{SO}_{2}$, and $\mathrm{CO}$, as well as toxic organic compounds such as polycyclic aromatic hydrocarbons, etc., may cause environmental problems ${ }^{4)}$. Recently, conversion by coal-tire coliquefaction has been achieved ${ }^{5)}$, but coal-tire coliquefaction requires large amounts of hydrogen to achieve high conversion.

Effective hydrogenation of dibenzothiophene (DBT) occurs by the partial oxidation of DBT-hexylbenzene mixture in supercritical water, possibly due to $\mathrm{CO}$ formation by the partial oxidation of hexylbenzene followed by conversion to hydrogenating species through the water-gas shift reaction $\left(\mathrm{CO}+\mathrm{H}_{2} \mathrm{O}=\mathrm{CO}_{2}+\mathrm{H}_{2}\right)^{6}$.

* To whom correspondence should be addressed.
Waste tires and coal are both organic compounds, so should be converted to $\mathrm{CO}$ by partial oxidation in supercritical water and then generate hydrogenating species through the water-gas shift reaction. The hydrogenating species can be expected to enhance the liquefaction process of the coal and tires. Thus, partial oxidation and the subsequent water-gas shift reaction should enhance coal-tire coliquefaction. In addition, use of supercritical water as a reaction medium would suppress mass transfer problems between the phases because the liquid product, oil from coal, is expected to form a homogenous phase in supercritical water.

The present study investigated the possible enhancement of the coliquefaction of waste tire and coal in supercritical water by partial oxidation and subsequent water-gas shift reaction. The effects on carbon conversion and liquid product were also assessed.

\section{Experimental Section}

\section{1. Experimental Apparatus and Methodology}

Supercritical water liquefaction was conducted in a tube-bomb reactor (SUS316, $9.53 \times 1.5 \times 147 \mathrm{~mm}$, $4.92 \mathrm{ml}$ ) as shown in Fig. 1. The temperature and pressure inside the reactor were measured by a K-type thermocouple and a pressure gauge, respectively. After placing $0.1 \mathrm{~g}$ of coal and/or waste tire, water, $\mathrm{H}_{2} \mathrm{O}_{2}$ solution, and $\mathrm{Ni}$ catalyst as required in the reactor, the reactor was immersed into a molten salt bath at $673 \mathrm{~K}$. Time needed for the temperature in the reactor to reach the reaction temperature was less than $1.5 \mathrm{~min}$. After the desired reaction time, the reactor was taken 




Fig. 1 Experimental Apparatus

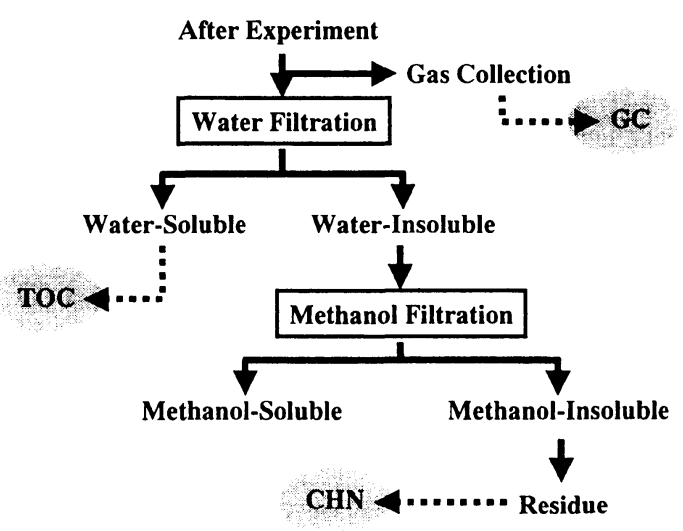

Fig. 2 Analysis Procedure

out of the salt bath and rapidly quenched in a cool water bath to terminate the reaction. The reaction time was $20 \mathrm{~min}$ for experiments investigating coliquefaction and the effects of oxygen addition and watergas shift reaction. Gas and liquid products were collected and analyzed.

Experiments were carried out with the weight fraction of coal in the $0.1 \mathrm{~g}$ of sample mixture of 0 (only tire), 0.5 , and 1 (only coal). $\mathrm{H}_{2} \mathrm{O}_{2}$ (30 wt\% solution, $0.04 \mathrm{~g}$ ) was added as oxidant in the partial oxidation experiments, which corresponds to $3 \%$ and $15 \%$ of the oxygen needed for complete combustion of the tire and coal, respectively. $\mathrm{Ni}$ catalyst $(0.04 \mathrm{~g})$ was loaded for catalytic experiments to promote the water-gas shift reaction. The amount of water was determined so that the pressure inside the reactor was $25 \mathrm{MPa}$ at $673 \mathrm{~K}$ Air in the reactor was replaced by inert gas, $\mathrm{He}$ or $\mathrm{N}_{2}$, to eliminate the possible effects of oxygen in the air.

\section{2. Analysis Procedure}

Figure 2 shows the analytical procedure. Product gas was collected in a pre-evacuated sampling bottle. The increase in pressure inside the bottle allowed calculation of the amount of the gas product. After collecting the gas products, solid and liquid products were
Table 1 Ultimate Analysis of Tire and Ishikari Coal Samples

\begin{tabular}{lcc}
\hline & Tire & Ishikari coal \\
\hline Carbon (daf) & 0.8865 & 0.4639 \\
Hydrogen (daf) & 0.0781 & 0.0504 \\
Nitrogen (daf) & 0.0017 & 0.0189 \\
Oxygen + Sulfur (daf) & 0.0337 & 0.4668 \\
Ash & 0.0590 & 0.0893 \\
\hline
\end{tabular}

thoroughly scraped out and washed out with $200 \mathrm{ml}$ of water into a separation trap, and filtered with a $0.3-\mu \mathrm{m}$ glass filter. Residue, which was defined as waterinsoluble product, was then dissolved in $100 \mathrm{ml}$ of methanol. Methanol-insoluble product was dried overnight in an oven at $333 \mathrm{~K}$, and weighed for the yield calculation. The calculation assumed that all ash in the sample was left in the residue. Minerals that could be dissolved in the water-soluble fraction were neglected. Thus, the weight of ash in the sample was subtracted from the weight of the methanol-insoluble product. Final analysis of the methanol-insoluble portion was conducted using a CHN analyzer (Yanagimoto Corp., MT-2). Gas composition was determined by GC-TCD/FID chromatography (Shimadzu Corp., GC14B). Water-soluble product was analyzed with a TOC analyzer (TOC-500) (see Fig. 2).

Unfortunately, the elemental composition of the methanol-soluble product could not be analyzed because of the interference of methanol solvent. Therefore, carbon conversion to methanol-soluble product was determined by subtracting the carbon conversions to gas and water-soluble product from total carbon conversion.

\section{3. Materials}

The waste tire sample was received from Muraoka Rubber Reclaiming Co., Ltd. Ishikari coal was used in this study. The results of the final analysis of the materials are shown in Table 1. The Ni catalyst was Engelhard Ni-5132P ( Ni+NiO supported on $\mathrm{SiO}_{2} / \mathrm{Al}_{2} \mathrm{O}_{3}$ support).

\section{Results and Discussion}

\section{1. Liquefaction of Coal and/or Waste Tire in Supercritical Water}

Figure 3 shows the amounts of product gases from liquefaction in all experiments. Liquefaction of coal formed more gas products than tires, partly due to the differences in composition, especially the oxygen content. Usually, compounds with high oxygen content are easily gasified in supercritical water. The Ishikari coal sample contains much more oxygen than waste tire (Table 1). The composition and amount of gas product matches the mean of the product from the liquefaction of the mixture of coal and tire, indicating that there was no interaction between the coal and tire in gas for- 




Fig. 3 Gas Product from Liquefaction and Coliquefaction with and without $\mathrm{H}_{2} \mathrm{O}_{2}$ and $\mathrm{Ni}$ Catalyst (per $0.1 \mathrm{~g}$ of sample)

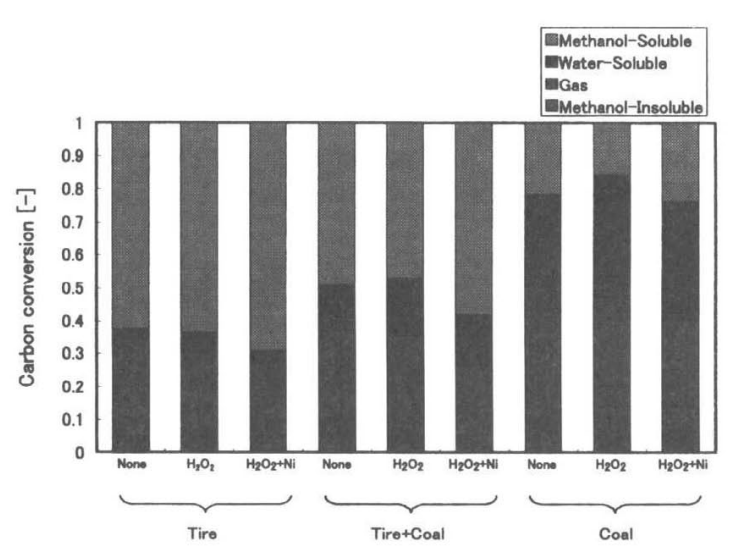

Fig. 4 Carbon Conversion to Each Product in Liquefaction and Coliquefaction with and without $\mathrm{H}_{2} \mathrm{O}_{2}$ and $\mathrm{Ni}$ Catalyst

mation. Figure 4 shows the carbon conversion to each product. Coal produced more water-soluble product than tire. Here again, the higher oxygen content in coal is likely to be the reason. More methanolsoluble product was formed from the coal-tire mixture, showing an interaction between tire and coal. In addition, the remaining carbon in the methanol-insoluble product from the coal-tire mixture was also lower than the mean of the individual coal and tire products, as shown in Fig. 5. Thus, a synergetic effect of coal-tire coprocessing occurs in the formation of char or asphaltene products, as measured by carbon in the methanolinsoluble product. Coal radicals may be stabilized by free radicals from the tire, which are smaller than those from coal in the conventional cotreatment of coal and tire $^{7) .8)}$. Therefore, a synergetic interaction between coal and tire can be also expected in supercritical water.

\section{2. Effect of $\mathrm{H}_{2} \mathrm{O}_{2}$ Addition}

Figure 3 shows the effect of $\mathrm{H}_{2} \mathrm{O}_{2}$ addition on the amounts and Fig. 4 shows the effect on carbon conversion for each product. $\mathrm{H}_{2} \mathrm{O}_{2}$ is clearly involved in carbon oxidation in all cases, as shown by the increase in

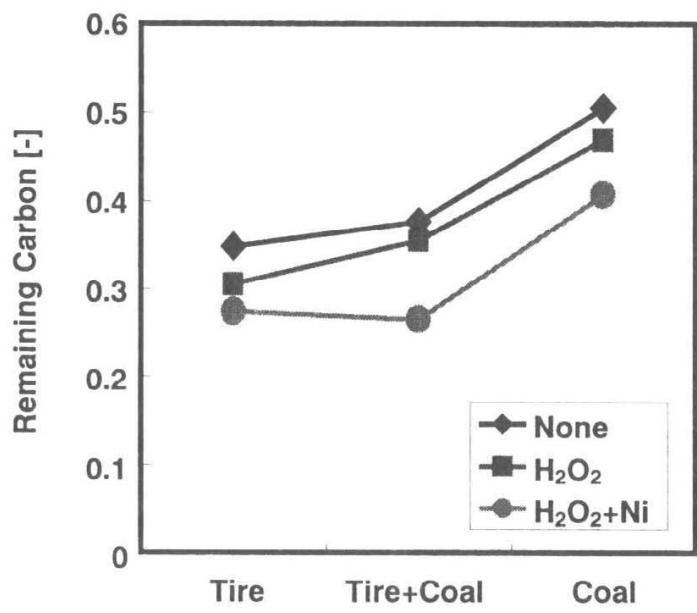

Fig. 5 Effect of $\mathrm{H}_{2} \mathrm{O}_{2}$ and Ni Catalyst on Residual Carbon in the Methanol-insoluble Product

gases containing carbon and corresponding decrease in the carbon content of the methanol-insoluble product, compared to the results without $\mathrm{H}_{2} \mathrm{O}_{2}$ addition.

The total amount of oxygen atoms in the gas product and the remaining oxygen content in the methanolinsoluble product (assuming a small amount of sulfur) was calculated to be more than the oxygen atoms from $\mathrm{O}_{2}$ (generated from $\mathrm{H}_{2} \mathrm{O}_{2}$ ), compared to the result in the absence of $\mathrm{H}_{2} \mathrm{O}_{2}$. The oxygen content in the methanol-soluble and water-soluble products are unknown, but this result indicates that there is another source of oxygen supply, which is probably the water.

The decrease in carbon content in the methanolinsoluble product was balanced by the increase in gases containing carbon in the case of tire, as shown in Fig. 4. This implies that the additional $\mathrm{H}_{2} \mathrm{O}_{2}$ resulted in direct oxidation of the tire. The decrease in carbon in the methanol-insoluble product for coal and the coaltire mixture is less than the increase in carbon in the gas and water-soluble products. This indicates that the carbon amount in the oil product (methanol-soluble product) is also affected by the additional $\mathrm{H}_{2} \mathrm{O}_{2}$.

\section{3. Effect of Water-gas Shift Reaction Promoted by Ni Catalyst}

The amounts of gas product shown in Fig. 3 indicate that $\mathrm{Ni}$ catalyst promotes the water-gas shift reaction in all cases, as shown by the increase in $\mathrm{H}_{2}$ in the gas product. Excess $\mathrm{O}_{2}$ in the gas product was observed in all cases with $\mathrm{Ni}$ catalyst, due to the dead volume of the reactor and the competition between direct oxidation and the water-gas shift reaction, which is accelerated by $\mathrm{Ni}$-catalyst.

Carbon conversion to methanol-soluble product increases in the presence of $\mathrm{Ni}$ catalyst (Fig. 4), indicating that Ni-catalyst both promotes carbon hydrogenation and enhances the selectivity for methanol-soluble product in all cases, especially for coal-tire mixtures. 
The amount of residual carbon in the methanol-insoluble product, as shown in Fig. 5, emphasizes the greater effect of $\mathrm{H}_{2} \mathrm{O}_{2}$ and $\mathrm{Ni}$ catalyst addition for the coal-tire mixture. Therefore, interaction between tire and coal radicals and hydrogenation via the water-gas shift reaction promoted by $\mathrm{Ni}$ catalyst are both important.

\section{Conclusions}

(1) Coal-tire coliquefaction is enhanced in supercritical water.

(2) $\mathrm{H}_{2} \mathrm{O}_{2}$ increases carbon oxidation for both coal and tire

(3) Hydrogenation is more important for coal than tire.

(4) Further enhancement in total conversion can be expected due to the interaction between coal and tire radicals and the water-gas shift effect promoted by $\mathrm{Ni}$ catalyst.

\section{Acknowledgments}

The authors would like to thank the TJTTP (Thailand-Japan Technology Transfer Project) for providing a scholarship and the opportunity to study abroad and do this research in Japan. This research is partly supported by Arai Foundation.

\section{References}

1) Kershaw, J. R., Fuel, 77, 1113 (1998).

2) Environmental News Paper (Japanese), Feb-9, 12 (2000)

3) Industrial Information Center, Office of Industrial Economics, Thailand.

4) Levendis, Y. A., Atal, A., Carlson, J., Dunayevskiy, Y., Vouros, P., Environ. Sci. Techonol., 30, 2742 (1996).

5) Davidson, R. M., "Coprocessing waste with coal," IEA Coal Research, (1997).

6) Adschiri, T., Shibata, R., Sato, T., Watanabe, M., Arai, K., Ind. Eng. Chem. Res., 37, 2638 (1998).

7) Sharma, R. K., Zondlo, J. W., Dadyburjor, D. B., Energy \& Fuels, 12, 589 (1998).

8) Liu, Z., Zondlo, J. W., Dadyburjor, D. B., Energy \& Fuels, 8, 607 (1994).

要旨

\title{
石炭と廃タイヤの超臨界水液化: 部分酸化と水性ガスシフト反応の影響
}

\author{
Prapan KUCHONTHARA ${ }^{\dagger 1}$ ， 松村 幸彦†2) \\ 11) 東京大学大学院工学系研究科化学システム工学専攻, 113-8656 東京都文京区本郷 7-3-1 \\ (2) 広島大学大学院機械システム工学専攻, 739-8527 広島県東広島市鏡山1-4-1
}

石狩草炭と廃夕イヤをそれぞれ単独，および混合物の超臨界 水液化することにより，两者の共液化による相乗効果を明らか にした。加えて部分酸化と水性ガスシフト反応が超臨界水中の 液化特性に及ほす影響についても明らかにした。実験は回分式 反応器を用い $673 \mathrm{~K}, 25 \mathrm{MPa}$ の条件で行った。ニッケル触媒
存在下での生成ガスは, 無触媒の時と比較すると, $\mathrm{H}_{2}$ の生成 が増加, $\mathrm{CO}$ の生成が減少したため，ニッケル触媒に水性ガス シフト反応の促進作用があることが確認できた。石炭と夕イヤ を共液化することにより, 特にニッケル触媒存在下で炭素転化 率が向上することを確認した。

\section{Keywords}

Liquefaction, Coal, Waste tire, Supercritical water 